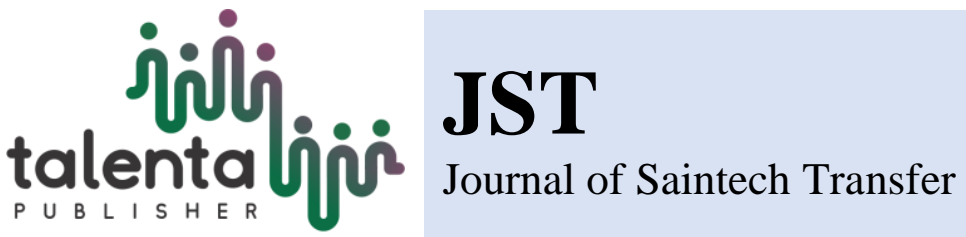

\title{
Training of Utilization of Coconut Dregs Flour and Its Processed Product to Increase Fiber Consumption in Tumpatan Village, Beringin Sub-District
}

\section{Tiar Lince Bakara*and Novriani Tarigan \\ ${ }^{1)}$ Department of Nutrition, Polytechnic of Health, Medan, Indonesia}

\begin{abstract}
The average national proportion of fewer-vegetables consumption for the population above 10 years is around 93.5\%. Fiber can be obtained from fruits, vegetables, and coconut dregs which can be processed into various types of food. The utilization of coconut dregs as a source of fiber has not been revealed much and has been only used as animal feed and "tempebongkrek". The main purpose of this community service was to improve skills of women cadres and members of PKKgroup about how to processcoconut dregs into brownies, cookies, and steamed cakes.The community service activities were conducted from March to September 2017 in Tumpatan Village, Beringin Sub-District. The activities consisted of three stages: pre-intervention, intervention, and post-intervention. In the intervention stage, some activities conducted were including training, socialization, and cooking demonstration of brownies, cookies, and steamed cakes. Based on the results of the intervention, the women cadres and members of PKK groupunderstood the benefits and functions of processed coconut dregs flour, and the advantages of food using coconut dregs flour. In addition, the women cadres andmembers of PKK group would be able to process coconut dregs and make snacks, such as brownies, cookies, and steamed cakes. The training activities of coconut dregs processing improved skills of the women cadres and members of PKK group in utilizing materials which have not been widely used as food ingredients.
\end{abstract}

Keywords: Brownies, Coconut Dregs Flour, Cookies, Steamed Cakes

Abstrak: Proporsi rerata nasional konsumsi kurang sayur pada penduduk diatas 10 tahun mencapai 93,5\% [1]. Serat dapat diperoleh dari buah dan sayuran, juga dari ampas kelapa yang diolah menjadi berbagai jenis makanan. Pemanfaatan ampas kelapa sebagai sumber serat selama ini belum banyak terungkap dan hanya dimanfaatkan sebagai pakan ternak dan tempe bongkrek. Tujuan pengabdian ini adalah untuk meningkatkan keterampilan kelompok kader dan ibu-ibu PKK tentang pengolahan ampas kelapa menjadi brownies, cookies, dan bolu kukus. Kegiatan *Corresponding author at: Jalan Negara Simpang Tanjung Garbus Lubuk Pakam

E-mail address:tiarlincebakara@gmail.com 
pengabdian masyarakat dilakukan di desa Tumpatan Kecamatan Beringin pada bulan Maret - September 2017. Kegiatan terdiri dari pra intervensi, intervensi, dan pasca intervensi. Pada intervensi dilakukan pelatihan, penyuluhan, dan demo masak brownies, cookies, dan bolu kukus. Dari hasil intervensi yang dilakukan kelompok kader dan ibu-ibu PKK memahami manfaat dan fungsi olahan tepung ampas kelapa serta kelebihan makanan yang menggunakan tepung ampas kelapa. Selain itu kelompok kader dan ibu-ibu PKK menjadi mampu dan terampil dalam mengolah ampas kelapa dan menjadikan snack yaitu brownies, cookies, dan bolu kukus. Kegiatan penyuluhan dan pelatihan pengolahan ampas kelapa meningkatkan kemampuan kelompok kader dan ibu-ibu PKK dalam memanfaatkan bahan yang selama ini belum sepenuhnya digunakan sebagai bahan makanan.

Kata Kunci: Bolu Kukus, Brownies, Cookies, Tepung Ampas Kelapa

Received 22 October 2017 | Revised 10 December 2017 | Accepted 9 March 2018

\section{Introduction}

Food is anything derived from biological sources of agricultural, plantation, forestry, fishery, farms, and water products, both processed and unprocessed for food or beverages of human consumption, including food additives, raw ingredients, and other ingredients used in the process of storage, processing, and/or production of food and beverage [2].

Compared with proteins, fats, and carbohydrates, discussion about dietary fiber is often underestimated. Fiber is part of the food which is not easily absorbed by human body; thus, its nutritional contribution can be ignored. However, dietary fiber has an important function which cannot be replaced by other substances. Fiber can be obtained from fruits and vegetables. Ranakusuma explains that dietary fiber is useful to reduce caloric intake. A low-calorie balanced diet with a high-fiber diet is beneficial as a strategy for dealing with obesity [3].

Research and Development Department of Ministry of Health of Indonesia showed the average national consumption of fewer vegetables and fruits for the population above 10 years old reached 93.5\% [4]. This percentage did not show much changes from the previous data of Riskesdas at 93.6\% [5]. Nevertheless, this result is in accordance with records of World Health Organization (WHO) which shows that Indonesian people only consume fruits and vegetables 2.5 portions per day or $34.55 \mathrm{~kg}$ per year. This amount is far below the recommendation of Food Agriculture Organization (FAP) for fruits consumption per capita per year which is $73 \mathrm{~kg}$.

Food fiber, also known as dietary fiber, is part of a plant which can be consumed. It is composed of carbohydrates resistant to digestive process and absorption in the small intestine of humanand experience partial or complete fermentation in the large intestine [6]. 
Herminingsih defines dietary fiber as the rest of plant cell walls which are not hydrolyzed or digested by human digestive enzymes including hemicellulose, cellulose, lignin, oligosaccharide, pectin, gum, and waxy coating [7]. On the other hand, Meyer defines fiber as an integral part of the food consumed daily, and the main sources are from plants, vegetables, cereals, fruits, and nuts [8].

Fiber, which can be obtained from fruits and vegetables, can also be obtained from coconut dregs which might be processed into various types of processed food. The utilization of coconut dregs as a source of fiber has not been revealed much, and it has been only used as animal feed and "tempe bongkrek". To gain a more qualified value, coconut dregs can be processed into coconut dregs flour. 100 gr of coconut dregs flour contains $33.64 \%$ carbohydrate, 5.78\% protein, and $15.07 \%$ crude fiber [9]. The content of nutrient-by-product of coconut dregs has a high value if used as a low-fat food ingredient. Coconut dregs flour can be used as the raw ingredient for making biscuits [10], brownies [11], and sweet bread, white bread, nugget, and spring rolls [12]. Based on these studies, coconut dregs flour can be utilized in the preparation of various types of processed food to substitute some wheat flour. The content of crude fiber in $100 \mathrm{gr}$ coconut dregs flour is $15.07 \%$; thus, this value could fulfill the suggested fiber intake. The suggested fiber intake for an adult is $19-30 \mathrm{~g} / \mathrm{kcal} /$ day whereas for children is $10-14 \mathrm{~g} / 1000 \mathrm{kcal}$ [13].

The main purpose of this community service was to improve skills of the women cadres and members of PKK group about the processing of coconut dregs into brownies, cookies, and steamed cakes. The benefits of these activities were to increase knowledge of women cadres and members of PKK group to be adept at processing coconut dregs into coconut dregs flour, to process dregs into high economic value products, and to increase the income of villagers from the sales of processed food of coconut dregs.

\section{Method}

The community service was held in Tumpatan Village, Beringin Sub-District. The activities of this community service were held from March to September 2017. There were three stages of activities undertaken during this community service, namely:

\subsection{Pre-Intervention}

a. Ask the willingness of women cadres and members of PKK group to conduct a screening in advance about the benefits and aims of the activities to be held.

b. Once the participants were identified, the community service activities were explained in details and they were asked for their willingness to participate by signing. 


\subsection{Intervention}

The community service activities were conducted in the form of training, socialization, and cooking demonstrations of various types of food by utilizing coconut dregs. The socialization about the benefits of coconut dregs was held in two stages, such as:

a. Stage I: The socialization was held simultaneously (all cadres and women members of PKK group). The methods used were public lecture or public speaking, and the use of media in the form of leaflets. This activity was held in the village hall of Tumpatan in the duration of 120 minutes.

Topics of the socialization:

1) What is coconut dregs flour?

2) Ingredients required to make processed food from coconut dregs flour

3) Benefits and functions of processed food from coconut dregs flour

4) Differences of food with and without the use of coconut dregs flour

5) The advantages of food using coconut dregs flour

6) Procedure of making coconut dregs flour and the its processed food products

7) Making brownies

8) Making cookies

9) Making steamed cakes

b. Stage II:

1) Conduct a cooking demonstration where each group of PKK cadres and women were invited to come to the village hall as the place of training and cooking demonstrations. The training or cooking demonstrations were conducted twice. These activities were adapted to the circumstances and schedule of the PKK cadres and women.

2) Each group of PKK cadres and women targeted were also trained on the processing of coconut dregs flour.

\subsection{Post-Intervention}

The last activity was to provide an opportunity for the participants to make brownies, cookies, and steamed cakes. 


\subsection{Tools and Materials}

The tools used in the cooking demonstrations were as follows: a blender, a mixer, a Waskom, cake pans, cormorants, a gas stove, an oven, a cabinet dryer, plates, spoons, knives, steamed cakes molds, a cutting board, and cookies molds.

\subsection{Participants}

The targets of the community service activities were women cadres and members of PKK group, housewives, secretaries of the village, reviewers, nutrition university students, and nutrition lecturers.

\subsection{Obstacles encountered}

One major obstacle encountered during the community service in Tumpatan Village was gathering the participants (i.e. housewives and women cadres). For example, the socialization was scheduled at $1 \mathrm{pm}$; however, the activity was postponed to $1.30 \mathrm{pm}$ because the participants had to pick up their children from school and prepare lunch at home. After completing their house chores, the participants finally came to the hall of Tumpatan Village to attend the training. Other participants (e.g. lecturers, university students, and women cadres and members of PKK group) have waited at the hall.

\subsection{Efforts to solve the obstacles}

Efforts to solve the obstacle encountered during the implementation of community service were by providing input and suggestions to re-invite and gather the villagers, especially housewives, so that they would continue attending the training of coconut dregs processing as the source of fiber in the group of cadres and housewives.The agreed decision with the training participants was that the next training should be started in the evening, so all housewives would be able to attend the activities held by Tumpatan villagers.

\section{8 . The success assessment of the activities}

After finishing the training of coconut dregs processing and cooking demonstration, the participants were given the opportunity to make cakes according to the taught recipes. The participants were enthusiastic and asked some questions during the cooking process, such as the purpose of including coconut dregs in the cake processing. The participants forgot the fact that coconut dregs contain fiber which is good for digestion. Cakes are usually processed with some high-calorie ingredients, such as eggs, milk, margarine, and granulated sugar; thus,by using coconut dregs, the processed cakes would not only contain high-calorie sources, but also fiber. 


\section{Results and Discussion}

\subsection{Pre-Intervention}

a. In the first meeting, the target number of participants for this community service was 30 participants consisted of women cadres and housewives in Tumpatan Village. However, 36 people attended the training of coconut dregs processing held on 12 September 2017. This number exceeded the predetermined number of participants.

b. Prior to the intervention, pre-intervention activity was conducted to explain the procedure of training and cooking demonstrations and to explain topics in the middle of cooking demonstrations.

\subsection{Intervention}

\section{Stage I}

The training activity was held in Tumpatan Village, Beringin Sub-District. The duration of training and cooking demonstrations was 2 hours with the use of leaflets. All participants were enthusiastic during the explanation about coconut dregs because they were not familiar with this material before. Topics presented in the socialization were as follows:

1) What is coconut dregs flour?

Coconut dregs flour is dried coconut dregs, pounded into a flour using a 100-mesh sieve, and processed with hygienic into raw ingredients of food [12].

2) Ingredients of making coconut dregs flour

Coconut dregs which have been squeezed were dried using a cabinet dryer, and then it was mashed using a blender and sieved.

3) Benefits and functions of coconut dregs flour

Coconut dregs flour is a low-fat food ingredient, or as a source of fiber which can be used as a raw ingredient of some food: biscuits [10]; brownies [11]; sweet bread, white bread, nugget, and spring rolls [12].

4) Procedure of making coconut dregs flour Ingredients required to make coconut dregs flour were:

a. Ingredients $=$ From 20 coconuts, $3300 \mathrm{~g}$ of dregs were obtained, and then dried.

b. After the dried coconut dregs were blended, the amount of $990 \mathrm{~g}$ was obtained.

\section{Stage II}

In the stage II, the training of utilizing coconut dregs flour was conducted with the method of cooking demonstrations in Tumpatan Village office. The recipes discussed in the cooking demonstrations were steamed cakes, cookies, and brownies. 


\subsection{Post-Intervention}

After the cooking demonstrations, the participants tried to process the recipes and make steamed cakes, cookies, and brownies by themselves.

\section{Conclusion}

It is evident that the socialization and training of coconut dregs processing have improved the skills of the women cadres and members of PKK group in utilizing materials which have not been widely used as food ingredients.

\section{References}

[1] Anonimus, 2001.The Definition of Dietary Fibre. Cereal Foods World 46:pp. 89-148. http:// www.aaccnet.org/Dietary Fiber/pdfs/ dietfiber.pdf. dalam Santoso, Agus. 2011. Serat Pangan (dietary fiber) dan manfaatnya bagi kesehatan. Jurusan Teknologi Hasil Pertanian, Fakultas Teknologi Pertanian, Unwidha Klaten

[2] Badan Standarisasi Nasional. 2011. SNI 2973:2011: Biskuit

[3] Balitbang Kemenkes RI. 2013. Riset Kesehatan Dasar; RISKESDAS. Jakarta

[4] Hardinsyah and Tambunan, V. 2004. Angka Kecukupan Energi, Protein dan Serat Makanan. Dalam Soekirman(Eds.), Ketahanan Pangan dan Gizi di Era Otonomi Daerah dan Globalisasi. Pro-siding Widyakarya Nasional Pangan dan Gizi VIII (hlm. 317-330), 17-19 Mei. LIPI, Jakarta. Dalam Kusharto, Clara. M. 2006. Serat makanan dan peranannya dalam kesehatan. JurnalGizidanPangan

[5] Herminingsih, A. 2010. ManfaatSeratdalam Menu Makanan. Universitas Mercu Buana, Jakarta. In: Santoso, Agus. 2011. Serat Pangan (dietary fiber) dan manfaatnya bagi kesehatan. Jurusan Teknologi Hasil Pertanian, FakultasTeknologi Pertanian, Unwidha Klaten.

[6] Putri, M.F. 2010 ${ }^{a}$. Kandungan Gizi dan Sifat Fisik Tepung Ampas Kelapa sebagai Bahan Pangan Sumber Serat. Fakultas Teknik UNNES. Semarang

[7] Putri, M. F. 2010 . Tepung Ampas Kelapa pada Umur Panen 11-12 Bulan sebagai Bahan Pangan Sumber Kesehatan. Jurusan Teknologi Jasa dan Produksi UNNES. Semarang

[8] Ranakusuma B. 1990. Obesitas dan Manfaat Serat. Gizi Indonesia, 15 (1), 76-80. Dalam Kusharto, Clara. M. 2006. Serat makanan dan peranannya dalam kesehatan. Jurnal Gizi dan Pangan

[9] Setiawati, Rahimsyah, A., and Ulyarti. 2015. Kajian Pembuatan Brownies Kaya Serat dari Tepung Ampas Kelapa. Fakultas Teknologi Pertanian, Universitas Jambi. Jambi

[10] Widarta, I. W.R, Suter, I K., Yusa, N M., Wiadnyani, A.A.I.S., and Puspawati, N.N. 2013. Pelatihan Pengolahan tepung Ampas Kelapa menjadi Biskuit di Desa Adat Panglipuran, Kabupaten Bangli. Jurusan Ilmu dan Teknologi Pangan, Fakultas Teknologi Pertanian, Universitas Udayana. Bali 